УДК 504.05.54:631.445

(C) 2014

Іваценко Т. Г., кандидат технічних наук, Пушкарьова І. Д., кандидат технічних наук

Державна екологічна академія післядипломної освіти та управління Мінприроди України

\title{
ВИЗНАЧЕННЯ ЗАБРУДНЮЮЧИХ РЕЧОВИН ГРУНТУ ТЕРИТОРІЙ ПРОМИСЛОВИХ ПІДПРИЕМСТВ ТА ІДЕНТИФІКАЦІЯ ЇХ ЕКОЛОГІЧНОЇ НЕБЕЗПЕКИ
}

\section{Рецензент - кандидат технічних наук Ю. М. Сорока}

У роботі наведено результати якісного й кількісного аналізу забруднюючих речовин трунту територіі промислового підприємства, шуо зупинило свою діяльність, а саме Сакського державного хімічного заводу. Встановлено, щзо в пробах трунту знаходиться щзонайменше 26 забрудників, п'ять з яких відносяться до речовин периого класу небезпеки. Досліджено концентрації забрудників та виявлено, щчо в окремих пробах вони перевищують граничнодопустимі у 2-295 разів. Висвітлено фактори екологічної небезпеки окремих забрудників, зокрема впливу на організм людини.

Ключові слова: трунти, забрудники, екологічна небезпека, важкі метали, якісний і кількісний аналіз, гранично допустима концентрачія.

Постановка проблеми. Особливостями розвитку антропогенних процесів у промислових регіонах є формування якісно нових біохімічних провінций. Це супроводжується комплексною поліелементною металізацією за наступною ланкою: джерела забруднення (викиди, відходи, стік) - депонування (грунт, донні виклади) та головні життєзабезпечуючі середовища (повітря, вода, продукти харчування) - організм людини. Обсяги надходження у довкілля важких металів унаслідок техногенного навантаження у сотні та тисячі разів перевищують їх фонові концентрації, що у глобальному масштабі дорівнює або перевищує їх промисловий видобуток.

Важлива роль у циркуляції важких металів у довкіллі належить грунтам. Вони - ключове середовище наземних екосистем, яке має універсальні адсорбційні властивості. Безперечно, саме грунт відображає рівень багаторічного антропогенного впливу на довкілля в цілому. У разі насичення грунту ксенобіотиками, грунт може стати джерелом вторинного забруднення для водойм, атмосферного повітря, для кормів тварин і продуктів харчування людини. На відміну від інших середовищ (наприклад, повітря, де переважають процеси розсіювання), у грунтів відсутня мож- ливість їх швидкого очищення. Тому хімічні забруднювачі можуть зберігатися в ньому довгі роки $\mathrm{i}$, включаючись до екологічних ланцюгів, обумовлювати тривалу дію токсикантів. Це підвищує ризик виникнення хронічних інтоксикацій.

Тому ключове положення, яке займає грунт у наземних екосистемах, робить екологічну оцінку наслідків його забруднення вкрай важливою, а багатофункціональність, полікомпонентність і гетерогенність цього природного тіла - надзвичайно важкою. Складність регламентації допустимого навантаження на грунт призвела до явної недостатності та недосконалості нормативної бази, що неодноразово відзначалося провідними вченими. До цього часу в Україні основним способом оцінки забруднення грунту важкими металами є порівняння з гранично допустимими концентраціями, які базуються на методології $70-80$-х років минулого сторіччя $[2,5]$.

Аналіз останніх досліджень і публікацій, у яких започатковано розв'язання проблеми. Увага науковців та громадськості прикута до впливу на навколишнє середовище підприємств, що працюють у стаціонарному режимі, але значний негативний вплив на стан навколишнього середовища спричиняють підприємства, діяльність яких припинено за тих чи інших обставин. Особливо, підприємства хімічної промисловості, відходи діяльності яких не утилізовано, а накопичено та розміщено на покинутій території підприємств. Більшість таких об'єктів характеризуються тим, що відходи розміщені безпосередньо на їх території, а не в облаштованих складах, які б запобігали розповсюдженню небезпечних компонентів відходів у навколишньому середовищі.

Результати таких досліджень у літературних джерелах практично відсутні. Тож досить актуальним $\epsilon$ питання дослідження як якісного, так і кількісного вмісту забруднюючих речовин у грунтах територій підприємств, що припинили свою діяльність, як фактора особливої екологічної небезпеки поширен- 
ня забруднень та їх безпосереднього впливу на здоров'я людини [4, 6-7].

Мета досліджень - 3'ясувати стан забруднення грунтів територій промислових підприємств, що зупинили свою діяльність (на прикладі Сакського державного хімічного заводу).

Завдання: встановити якісний і кількісний склад забруднюючих речовин грунту та ідентифікувати їх екологічну небезпеку.

Результати досліджень. Для встановлення якісного і кількісного складу забруднюючих речовин грунту території промислових підприємств, що зупинили свою діяльність, об'єктом дослідження було обрано грунти території Сакського державного хімічного заводу. Сакський державний хімічний завод (CX3) - один із найбільших хімічних заводів Криму. У 60-х роках минулого століття на СX3 почалося виробництво перманганату натрію (відбілювач), калію й амонію бромистих (добрива), бромистого метилу (інсекте- цид) та ін. 31973 року на території хімічного заводу було запущено цех із виробництва перманганату калію.

Загалом у минулому СХЗ стабільно працював і виробляв більше ніж 40 видів хімічної продукції. Зокрема, виробництво перманганату калію та бромистого метилу єдине у СНД. Бромистий метил $\left(\mathrm{CH}_{3} \mathrm{Br}\right)$ - органічна речовина, галогенпохідне метану, сильнодіюча отрута.

Фумігант, що використовувався для знезараження рослинних матеріалів від шкідників, зокрема щитівок, борошнистих червців, а також для боротьби зі шкідниками під час зберігання свіжих і сухих овочів і фруктів, рідше - для обробки зерна, також застосовувався під час обробки вживаного одягу.

Відходи виробництва бромистого метилу та інших хімічних речовин, що були основою виробництва СХ3, в основному небезпечні й містять значну кількість важких металів.

\section{1. Результати якісного та кількісного аналізування проб грунту територій СХЗ}

\begin{tabular}{|c|c|c|c|c|c|c|c|c|c|c|}
\hline \multirow{2}{*}{$\begin{array}{c}\text { № } \\
\text { з/п }\end{array}$} & $\begin{array}{c}\text { Якісний } \\
\text { склад } \\
\text { забруд- } \\
\text { нювачів }\end{array}$ & \begin{tabular}{c} 
проба \\
\cline { 3 - 11 }
\end{tabular} & $\begin{array}{c}\text { проба } \\
\text { прількісний склад, г/кг }\end{array}$ & $\begin{array}{c}\text { проба } \\
4\end{array}$ & $\begin{array}{c}\text { проба } \\
5\end{array}$ & $\begin{array}{c}\text { проба } \\
6\end{array}$ & $\begin{array}{c}\text { проба } \\
7\end{array}$ & $\begin{array}{c}\text { проба } \\
8\end{array}$ & $\begin{array}{c}\text { проба } \\
9\end{array}$ \\
\hline 1 & $\mathrm{Al}$ & 16,23 & 4,03 & 13,4 & 0,31 & 0,99 & 0,94 & 10,04 & 38,26 & 11,28 \\
\hline 2 & $\mathrm{As}$ & 0,012 & 0 & 0 & 0,017 & 0,032 & 0,028 & 0,033 & 0,027 & 0,04 \\
\hline 3 & $\mathrm{~B}$ & 0 & 0 & 0 & 0,02 & 0,02 & 0 & 0 & 0,017 & 0,047 \\
\hline 4 & $\mathrm{Ba}$ & 1,07 & 4,14 & 5,77 & 6,21 & 5,65 & 0,64 & 4,74 & 2,58 & 14,22 \\
\hline 5 & $\mathrm{Ca}$ & 102,2 & 161,9 & 29,24 & 48,77 & 71,98 & 152,4 & 116,9 & 53,29 & 242,1 \\
\hline 6 & $\mathrm{Cd}$ & 0 & 0 & 0 & 0,012 & 0,017 & 0,005 & 0 & 0 & 0 \\
\hline 7 & $\mathrm{Co}$ & 0,018 & 0,053 & 0,26 & 0 & 0 & 0 & 0,065 & 0,021 & 0,076 \\
\hline 8 & $\mathrm{Cr}$ & 0,042 & 0,2 & 0,5 & 1,87 & 1,35 & 0,23 & 0,09 & 0,083 & 0,11 \\
\hline 9 & $\mathrm{Cu}$ & 0,043 & 0,069 & 0,13 & 0,024 & 0,036 & 0,047 & 0,021 & 0,018 & 0,27 \\
\hline 10 & $\mathrm{Fe}$ & 26,26 & 23,14 & 24,44 & 228,65 & 284,53 & 154,25 & 15,47 & 37,98 & 13,99 \\
\hline 11 & $\mathrm{Ga}$ & 0 & 0 & 0 & 0,34 & 0,42 & 0,241 & 0 & 0,127 & 0 \\
\hline 12 & $\mathrm{Hg}$ & 0,005 & 0 & 0 & 0,005 & 0,005 & 0,005 & 0,005 & 0,005 & 0 \\
\hline 13 & $\mathrm{~K}$ & 21,27 & 77,67 & 191,2 & 3,97 & 7,07 & 2,90 & 148,9 & 34,34 & 30,34 \\
\hline 14 & $\mathrm{Li}$ & 0,041 & 0,041 & 0,041 & 0,041 & 0,041 & 0,041 & 0,089 & 1,05 & 0,022 \\
\hline 15 & $\mathrm{Mg}$ & 8,69 & 6,87 & 2,41 & 0,77 & 0,94 & 1,22 & 11,7 & 12,72 & 5,90 \\
\hline 16 & $\mathrm{Mn}$ & 33,15 & 229,9 & 285,4 & 0 & 0 & 0 & 65,93 & 0 & 124,2 \\
\hline 17 & $\mathrm{Na}$ & 0,50 & 3,34 & 3,24 & 4,14 & 4,75 & 2,44 & 5,34 & 11,75 & 4,36 \\
\hline 18 & $\mathrm{Ni}$ & 0,067 & 0,88 & 0,49 & 0,028 & 0,013 & 0,048 & 0,73 & 0,086 & 1,18 \\
\hline 19 & $\mathrm{P}$ & 0,63 & 0,24 & 0,094 & 0 & 0 & 0,12 & 1,74 & 0,52 & 3,66 \\
\hline 20 & $\mathrm{~Pb}$ & 0,048 & 0,091 & 0,46 & 0,37 & 0,53 & 0,12 & 0,029 & 0,039 & 0,023 \\
\hline 21 & $\mathrm{Sb}$ & 0 & 0 & 0,005 & 0,061 & 0,035 & 0,006 & 0 & 0 & 0 \\
\hline 22 & $\mathrm{Se}$ & 0,011 & 0,11 & 0,15 & 0,22 & 0,28 & 0,16 & 0,033 & 0,082 & 0,053 \\
\hline 23 & $\mathrm{Sr}$ & 0,49 & 3,29 & 2,19 & 0,43 & 0,74 & 0,54 & 3,84 & 0,23 & 0,74 \\
\hline 24 & $\mathrm{Tl}$ & 0,042 & 0,28 & 0,37 & 0,01 & 0,01 & 0,01 & 0,091 & 0 & 0,091 \\
\hline 25 & $\mathrm{~V}$ & 0,038 & 0,047 & 0,011 & 0 & 0 & 0 & 0,03 & 0,073 & 0,29 \\
\hline 26 & $\mathrm{Zn}$ & 0,19 & 0,32 & 0,99 & 0,072 & 0,089 & 0,080 & 0,083 & 0,11 & 0,27 \\
\hline
\end{tabular}




\section{TEХНІЧНІ НАУКИ}

Та у 1996-1998 рр. діяльність СХЗ було припинено. У 2004 р. підприємство було визнано банкрутом і на теперішній час знаходиться на стадії санації. За останні роки обладнання заводу було демонтовано та вивезено, будівлі й споруди зруйновано. Для встановлення якісного і кількісного складу забруднюючих речовин грунту на території СХЗ було відібрано дев'ять проб грунту в різних місцях території заводу [8]. Досліджували забруднювачі, що притаманні відходам даного специфічного виробництва, зокрема важкі метали та інші токсичні хімічні речовини.

Проби грунту було піддано багатоелементному хімічному аналізу за допомогою атомноемісійного спектрометру з індуктивно-зв'язаною плазмою IRIS Intreprid II XSP DUO виробництва фірми «Termo Elemental» (США) на базі ТОВ «Центр радіоекологічного моніторингу» м. Жовті Води. Результати якісного та кількісного аналізування проб грунту територій СХЗ наведені у таблиці 1. Якісний аналіз проб даного грунту показав, що в ньому наявні більше ніж 26 забруднюючих компонентів, більшість 3 яких $є$ важкими металами. Особливу небезпеку спричиняють важкі метали першого класу небезпеки, зокрема кадмій, ртуть, свинець, селен, цинк, миш'як. Так, небезпека забруднення грунту тим вища, чим більше фактичний вміст компонентів забруднення грунту понад ГДК, що може бути виражено коефіцієнтом Ко, який розраховується

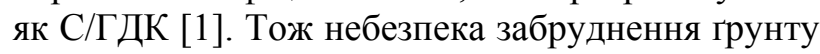

зростає у відповідності до перевищення одиниці коефіцієнтом Ко. Для забруднювачів, за якими спостерігали найбільші концентрації, а також для речовин першого класу небезпеки, проведені розрахунки коефіцієнта Ко. Оскільки, для деяких хімічних елементів, навіть таких, що відносяться до першого класу небезпеки (Cd та $\mathrm{Se})$, нормативи ГДК відсутні; для розрахунку коефіцієнту Ко використано діючі в Німеччині нормативи забруднювачів у грунті [9].

Подібні нормативи існують і в інших країнах Європи. Результати співвідношення вмісту деяких хімічних речовин у пробах грунту території СX3 до гранично допустимих їх рівнів, а також розрахованого коефіцієнт Ко, наведено в таблиці 2.

Із даних таблиці 2 бачимо, що концентрації більшості забруднювачів у пробах грунтів територій СХЗ, перевищують гранично допустиму у 2-295 разів. Так, результати екологічної оцінки забруднення грунтів за стандартною методикою визначення Zc (показника сумарного забруднення грунту), що викладені в роботі [4] за забрудниками першого класу небезпеки (важкими металами), демонструють, що грунти відносяться до III категорії забруднення - небезпечної. Такий стан забруднення грунтів характеризується підвищеною екологічною небезпекою та може викликати захворюваність населення, оскільки зокрема важкі метали першого класу небезпеки $є$ надзвичайно токсичними для організму людини.

\section{2. Результати розрахунків коефіцієнта Ко для найбільш небезпечних забруднювачів грунту територій СХЗ}

\begin{tabular}{|c|c|c|c|}
\hline Забруднювач & $\begin{array}{c}\text { Межі варіювання концентрацій } \\
\text { забруднювача у пробі грунту }\end{array}$ & ГДК, мг/кг & Ко \\
\hline $\mathrm{As}$ & $12-40$ & 2,0 & $6-20$ \\
\hline $\mathrm{Cd}$ & $5-17$ & 3,0 & $1,7-5,7$ \\
\hline $\mathrm{Hg}$ & 5 & 2,1 & 2,4 \\
\hline $\mathrm{Pb}$ & $23-460$ & 30,0 & $0,87-15,3$ \\
\hline $\mathrm{Zn}$ & $72-990$ & 23,0 & $3,13-43,0$ \\
\hline $\mathrm{B}$ & $17-47$ & 100,0 & $0,17-0,47$ \\
\hline $\mathrm{Ba}$ & $1070-14220$ & 200,0 & $5,35-71,1$ \\
\hline $\mathrm{Co}$ & $18-76$ & 5,0 & $3,6-15,2$ \\
\hline $\mathrm{Cr}$ & $42-1870$ & 6,0 & $7,0-311,7$ \\
\hline $\mathrm{Cu}$ & $18-270$ & 3,0 & $6,0-90,0$ \\
\hline $\mathrm{Mn}$ & $33150-285000$ & 1500,0 & $22,1-190,0$ \\
\hline $\mathrm{Ni}$ & $13-1180$ & 4,0 & $3,25-295,0$ \\
\hline $\mathrm{Sb}$ & $5-61$ & 4,5 & $1,1-13,5$ \\
\hline $\mathrm{Se}$ & $11-280$ & 10,0 & $1,1-28,0$ \\
\hline $\mathrm{Tl}$ & $10-370$ & 10,0 & $1,0-37$ \\
\hline $\mathrm{V}$ & $11-290$ & 150,0 & $0,1-1,93$ \\
\hline
\end{tabular}


Наприклад, солі $\mathrm{Cd}$ для людини характеризуються мутагенними та канцерогенними властивостями. У разі їх надлишкової концентрації блокується робота низки важливих для життєдіяльності організму ферментів, вражається печінка, нирки, підшлункова залоза. Кадмію притаманна здатність викликати емфізему, рак легенів. Se у людини викликає захворювання дихальних шляхів і порушення всіх систем органів. Поряд із цим негативна дія надлишку селену залежить від властивої йому хімічної спорідненості з гемоглобіном.

Він порушує функції гемоглобіну, знижує рівень тканинного дихання в організмі, й являється у 10 разів токсичнішим за свинець. Надлишок $\mathrm{Zn}$ для людини призводить до загальної інтоксикації та мутацій ДНК, сприяє діленню ракових клітин, спричиняє анемію, деформацію кісток, порушує газообмін і кислотність тканинної рідини

\section{БІБЛІОГРАФІЯ}

1. Гончарук Е. Г. Санитарная охрана почвы от загрязнения химическими веществами / Е. Г. Гончарук. - М. : Высшая школа, 1996. - 320с.

2. Польчина С. М. Грунтознавство / [I. I. Назаренко, С. М. Польчина, В. А. Нікорич] ; за ред. професора I. I. Назаренка. - К. : Вища освіта, 2004. $-400 \mathrm{c}$.

3. Екотоксикологія / [Снітинський В. В., Хiрівський П. Р., Гнатів П. С. та ін.]. - Херсон : Олді-плюс, 2013. - 330 с.

4. Іващенко Т. Г. Оцінка екологічного стану грунтів територій Сакського державного хімічного заводу / Т. Г. Іващенко, І. Д. Пушкарьова // Екологічна безпека. - 2014. - №1/2014(17). C. 64-68.

5. Кроїк Г. А. Токсикологічні аспекти накопичення та росподілу важких металів у грунтах промислових агломераций / Г. А. Кроїк // Біорізноманіття та роль тварин в екосистемах : матері- і плазми крові $[3,7]$.

Висновок. Результати дослідження якісного і кількісного складу забруднюючих речовин грунту території Сакського державного хімічного заводу демонструють значну екологічну небезпеку забруднення. Встановлено, що якісний склад забрудників грунту - понад 26, зокрема 5 з яких відносяться до важких металів першого класу небезпеки. В окремих пробах грунту концентрації забрудників перевищують гранично допустиму норму у 2-295 разів. Такий екологічний стан грунтів характеризується підвищеною небезпекою розвитку захворювань населення прилеглих територій.

Тож подальшими дослідженнями буде запропоновано методи запобігання поширенню забруднення та рекультивації грунтів для зменшення екологічної небезпеки досліджуваної території.

али VI Міжнародної наукової конференції. Дніпропетровськ : Вид-во ДНУ, 2011. - С. 15-18.

6. Національна доповідь про стан техногенної та природної безпеки в Україні у 2013 році [Електронний ресурс]. - Режим доступу:

http://www.mns.gov.ua/content/annual_report_2013. html

7. Старчак В. Г. Охорона техноприродних екосистем від техногенного забруднення / [В. Г. Старчак, І. Д. Пушкарьова та ін.] // Фальцфейнівські читання. - 2009. - С. 339-342.

8. Охрана природы. Почвы. Общие требования к отбору проб : ГОСТ 17.4.3.01-83. - [Чинний від 1984.01.07]. - М. : Государственный комитет по стандартам СССР. - 4 c.

9. Ständiger Ausschuss Altlasten der Bund / Länder-Arbeitsgemeinschaft Bodenschutz (LABO), 1, Stand : 21. Marz, 2006. 